\title{
Ensayo cometa
}

\section{Comet assay}

Luis Yamunaqué-Castro ${ }^{1, a}$, Fernando Rafael García-Bracamonte ${ }^{2, b}$, Luis Miguel Serquén-López 2,a

Los agentes genotóxicos (citostáticos, radiaciones, ciertos insumos químicos, etc.), causan daño a la estructura ADN, pudiendo generar rupturas en cadenas simples o dobles; y como consecuencia, introducir mutaciones en genes responsables del correcto funcionamiento celular.

Una de las pruebas de laboratorio para evaluar el daño genotóxico por estos componentes es el "ensayo cometa o técnica de electroforesis unicelular"; el cual permite medir la magnitud del daño mediante la visualización de núcleos de células sanas comparadas con aquellas que han sido expuestas. Estas últimas, debido a la fragmentación del ADN, se visualizan en forma de cola de cometa, a través de microscopía de flourescencia. Previo a la observación, la muestra de células deberá ser concentrada y tratada para someterlas a una corrida electroforética en microgeles, y luego teñilas con bromuro de etidio $^{(1)}$. Ver figura.

Se realizó el procedimiento para evaluar el daño del ADN de linfocitos humanos mediante la prueba de ensayo cometa, según procedimientos previamente descritos ${ }^{(2,3)}$. Las células mostradas en las microfotografías de la figura, fueron tratadas con diferentes concentraciones de $\mathrm{H} 2 \mathrm{O} 2$ durante 10 minutos; luego de la electroforesis y tinción con bromuro de etidio a $20 \mathrm{ug} / \mathrm{ml}$, se visualizaron los núcleos mediante microscopia de fluorescencia con filtros de $510 \mathrm{~nm}$ de absorción y $595 \mathrm{~nm}$ de emisión. Se observó que el daño del ADN fue proporcional a la concentración del $\mathrm{H}_{2} \mathrm{O}_{2}$, evidenciándose por el aumento del tamaño de la cola. El daño se mide en una escala de puntuación del 0 al 4 , según lo propuesto por Collins et al. ${ }^{(4)}$.

\footnotetext{
1. Facultad de Ciencias Biológicas, Universidad Nacional Pedro Ruiz Gallo, Lambayeque, Perú.

2. Laboratorio de Biología Molecular, Hospital Regional Lambayeque, Chiclayo, Perú.

a. Biólogo.

b. Tecnólogo médico.
} 


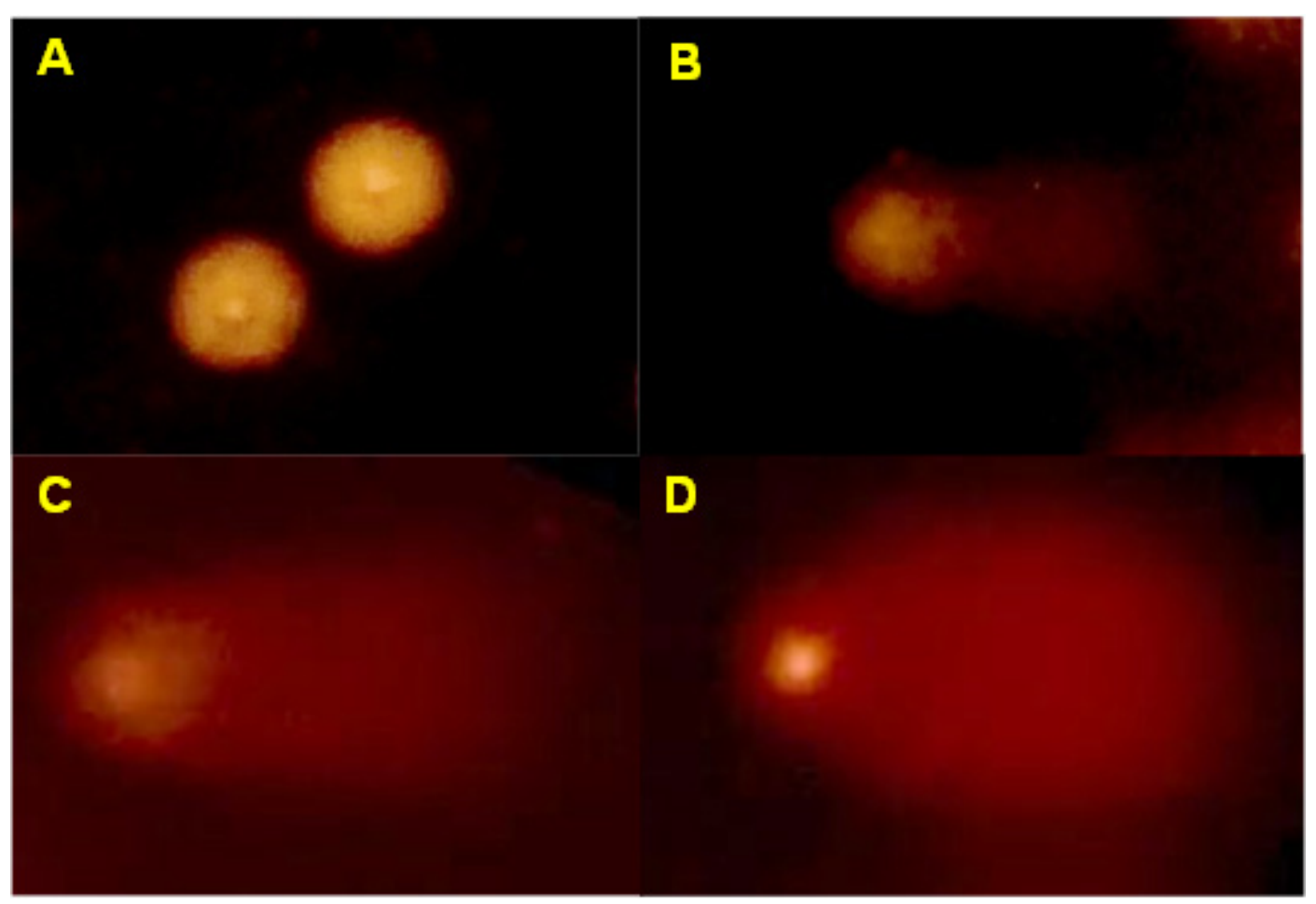

Figura. Microfotografías de fluorescencia de núcleos de linfocitos humanos tratados experimentalmente con peróxido de hidrógeno, mostrando distintas grados de daño del ADN (400 aumentos): A) control (no tratado), B) peróxido de hidrógeno 100 uM, C) Peróxido de hidrógeno 200 uM y D) Peróxido de hidrógeno 300 uM.

\section{REFERENCIAS BIBLIOGRÁFICA :}

1. Azqueta A, et al. DNA repair as a human biomonitoring tool; comet assay approaches. Mutat Res Repair. 2019; 781:71-87

2. Singh NP, McCoy MT, Tice RR, Schneider EL. A simple technique for quantitation of low levels of DNA damage in individual cells. Exp Cell Res. 1988; 175(1):184-91.
3. Santoro R, Ferraiuolo M, Morgano GP, Muti P, Strano S. Comet assay in cancer chemoprevention. Methods Mol Biol. 2016; 1379(1):99-105.

4. Collins AR, Ai-guo M, Duthie SJ. The kinetics of repair of oxidative DNA damage (strand breaks and oxidised pyrimidines) in human cells. Mutat Res Repair. 1995; 336(1):69-77. 